\title{
PENGARUH PENAMBAHAN TEPUNG BONGGOL PISANG PADA PAKAN TERHADAP BERAT KARKAS, PERSENTASE KARKAS, DAN LEMAK ABDOMINAL AYAM PEDAGING
}

\author{
Influence of addition of Banana Corm in Feed on Carcass Weight, Carcass \\ Percentage, and Abdominal Fat of Broiler \\ Dwi Kiat Puspitasari ${ }^{1)}$, Osfar Sjofjan ${ }^{2)}$, Eko Widodo ${ }^{2)}$ \\ 1) Mahasiswa Fakultas Peternakan Universitas Brawijaya Jalan Veteran, Ketawanggede, Kec. Lowokwaru, \\ Kota Malang, Jawa Timur 65145 \\ ${ }^{2)}$ Dosen Fakultas Peternakan Universitas Brawijaya Jalan Veteran, Ketawanggede, Kec. Lowokwaru, Kota \\ Malang, Jawa Timur 65145 \\ Email : $\underline{\text { dwikiatp@gmail.com }}$
}

\begin{abstract}
ABSTRAK
Tujuan penelitian ini adalah untuk mengevaluasi pengaruh penambahan tepung bonggol pisang terhadap berat karkas, persentase karkas, dan lemak abdominal ayam pedaging. Hasil dari penelitian ini diharapkan dapat menjadi solusi sebagai pakan alternatif untuk mengurangi biaya produksi pakan. Bahan yang digunakan adalah 100 DOC strain New Lohmann MB-202 yang diproduksi oleh PT. Japfa Comfeed Indonesia dengan koefisien keragaman 8,41\%. Metode yang digunakan adalah eksperimen menggunakan Rancangan Acak Lengkap (RAL) dengan 5 perlakuan dan 4 ulangan. Terdapat 20 kelompok di mana setiap kelompok terdiri dari 5 ayam. Perlakuan yang digunakan sebagai berikut, $P_{0}$ : pakan basal, $P_{1}:$ pakan basal + $2,5 \%$ tepung bonggol pisang, $P_{2}:$ pakan basal $+5 \%$ tepung bonggol pisang, $P_{3}:$ pakan basal $+7,5 \%$ tepung bonggol pisang, $P_{4}$ : pakan basal $+10 \%$ tepung bonggol pisang. Variabel yang diukur adalah berat karkas, persentase karkas, dan lemak abdominal ayam pedaging. Data dianalisis dengan menggunakan Analysis of Variance (ANOVA), apabila terdapat perbedaan pengaruh maka dilanjutkan dengan Uji jarak berganda Duncan's (UJBD). Hasil penelitian menunjukkan bahwa perlakuan tidak berpengaruh secara signifikan $(P>0,05)$ terhadap berat karkas, tetapi berpengaruh nyata $(P<0,05)$ terhadap persentase karkas dan berpengaruh sangat nyata $(P<0,01)$ terhadap lemak abdominal ayam pedaging. Kesimpulannya adalah penambahan tepung bonggol pisang di dalam pakan dapat diberikan maksimum sebanyak $10 \%$.
\end{abstract}

Kata kunci: Bonggol pisang, bobot karkas, persentase karkas, lemak abdominal, broiler

How to Cite :

Puspitasari, D. K., Sjofjan, O., \& Widodo, E. (2019). Pengaruh Penambahan Tepung Bonggol Pisang pada Pakan Terhadap Berat Karkas, Persentase Karkas, dan Lemak Abdominal Ayam Pedaging. Jurnal Nutrisi Ternak Tropis, 2 (1) 33-41
*Corresponding author :

Dwi Kiat Puspitasari

Email : dwikiatp@gmail.com

Fakultas Peternakan Universitas Brawijaya Jalan Veteran, Ketawanggede, Kec. Lowokwaru, Kota Malang, Jawa Timur 65145 


\section{ABSTRACT}

The aim of this research was to evaluate the influence of the addition of banana corm feed on the weight of the carcass, carcass percentage, and abdominal fat of broiler. The result of this research was expected to be a solution for alternative feed to reduce the cost production of feed. Materials used were 100 DOC New Lohmann MB-202 strain was produced by PT. Japfa Comfeed Indonesia with a coefficient of variation $8.41 \%$. The methods used was experiment in Completely Randomized Design (CRD) with 5 treatments and 4 replications. There were 20 flocks in which each group consisted of 5 chicks. The treatments were as follows, $P_{0}$ : basal diet, $P_{1}$ : basal diet $+2.5 \%$ banana corm, $P_{2}$ : basal diet $+5 \%$ banana corm, $P_{3}$ : basal diet $+7.5 \%$ banana corm, $P_{4}$ : basal diet $+10 \%$ banana corm. Variables measured were carcass weight, carcass percentage, and abdominal fat of broiler. The data was analyzed by using Analysis of Variance (ANOVA), If there was a significant effect it would be tested with Duncan's Multiple Range Test (DMRT). The result showed that treatments did not significantly influence $(P>0.05)$ on carcass weight, but signifcantly affected $(P<0.05)$ on carcass percentage and highly significantly influenced $(P<0.01)$ on abdominal fat. In conclusion the best addition of banana corm in broiler might be fed a maximum of $10 \%$.

Keywords :Banana corm, weight carcas, carcas percentage, abdominal fat, broiler

\section{PENDAHULUAN}

Peternakan ayam pedaging di Indonesia mulai berkembang pesat setiap tahun, menurut Direktorat Jenderal Peternakan dan Kesehatan Hewan (2016) pertumbuhan usaha peternakan ayam pedaging pada tahun 2016 terhadap 2015 sebanyak $6,1 \%$.

Seiring dengan peningkatan kesadaran masyarakat tentang konsumsi protein hewani nasional, terjadi peningkatan konsumsi daging ayam pada tiap tahun dengan total produksi pada tahun 2015 mencapai 1,628 juta ton, tahun 2016 sebanyak 1,689 juta ton. Kenaikan produksi ini diimbangi dengan keberhasilan faktor pemeliharan ternak ayam pedaging.

Faktor yang berpengaruh dalam pemeliharaan ini yaitu feeding, breeding, dan management. Pakan memiliki proporsi $70-80 \%$ dari total biaya produksi di dalam usaha peternakan ayam pedaging. Biaya yang tinggi menyebabkan dampak pada harga penjualan daging ayam pedaging yang mahal. Pemenuhan kebutuhan bahan pakan yang masih kurang inilah yang menyebabkan Indonesia harus impor yang dapat mempengaruhi peningkatan harga pakan.
Perlu adanya pemanfaatan bahan pakan lokal untuk menekan biaya produksi pemeliharaan dibanding harus bergantung pada pemenuhan bahan pakan dengan cara impor. Berdasarkan permasalahan yang ada pemanfaatan sumber bahan pakan lokal mutlak di lakukan. Rosidin, dkk. (2012) menyatakan bahwa pakan alternatif dari limbah pertanian berupa hasil samping merupakan salah satu upaya untuk mengurangi ketergantungan terhadap bahan baku impor dengan penggunaan bahan baku lokal yang lebih murah serta dapat disediakan dalam jumlah yang besar dan berkesinambungan.

Produksi tanaman pisang di Indonesia sangatlah tinggi dikarenakan mudah tumbuh dan dibudidayakan. Bonggol pisang merupakan bagian tanaman pisang yang berada pada bagian bawah batang pisang yang berada dibagian bawah tanah yang berupa umbi batang (batang asli). Kimiawi bonggol pisang kapok terdiri dari BK $91,56 \%$, PK 1,76\%, SK 10,6\%, LK 2,43\%, Ca 0,06 mg, P 0,15\%, EM 2227,56 Kkal/Kg. Berdasarkan potensi yang didapatkan di dalam bonggol pisang, maka dapat digunakan sebagai satu sumber energi bagi ternak unggas. Bahan pangan dapat dikatakan sebagai sumber energi apabila 
bahan pakan tersebut mengandung protein kasar kurang dari $20 \%$ serta serat kasarnya kurang dari 18\% (Sutardi, 2001).

\section{MATERI DAN METODE}

\section{Tempat dan Waktu Penelitian}

Penelitian ini telah dilaksanakan secara tim di peternakan ayam pedaging Bapak Syamsul Dusun Bunder, Desa Ampeldento, Kecamatan Karangploso, Kabupaten Malang, Jawa Timur selama 5 minggu yaitu, dari tanggal 11 Desember 2017 sampai dengan 16 Januari 2018. Analisis pakan dilaksanakan di Laboratorium Nutrisi dan Makanan Ternak, Fakultas Peternakan, Universitas Brawijaya, Malang.

\section{Materi Penelitan}

Penelitian ini menggunakan DOC (Days Old Chick) yang tidak dibedakan jenis kelaminnya (non-sexing) yang merupakan strain New Lohmann MB-202 yang merupakan hasil produksi PT. Japfa Comfeed Indonesia sejumlah 100 ekor dengan rataan bobot badan yang digunakan sekitar 35,91 $\pm 3,01$ g/ekor dengan koefisien keragaman bobot $8,45 \%$. Kandang pada penelitian ini dibuat kandang open house dengan sistem umbaran yang memiliki alas litter berupa sekam yang dapat menyerap kotoran ayam selama pemeliharaan. Kandang dibuat petak-petak yang terdiri dari 20 petak, dalam setiap petak memiliki panjang $100 \mathrm{~cm}$, lebar $100 \mathrm{~cm}$, dan tinggi 60 $\mathrm{cm}$. Bahan yang digunakan dalam pembuatan kandang adalah bambu.

Bonggol pisang berasal dari tanaman milik warga di daerah Ponorogo. Pisang kepok merupakan jenis pisang yang hampir seluruh daerah menanamnya sehingga produksi limbah yang dihasilkan juga banyak. Pembuatan menjadi tepung yaitu bonggol pisang bagian bawah yang telah dipisahkan dengan batangnya kemudian di potong secara kecil dan tipis-tipis dilanjutkan dengan penjemuran selama 2 sampai 3 hari dibawah sinar matahari.
Pakan yang digunakan dalam penelitian ini terdiri dari pakan basal: konsentrat ayam pedaging produksi dari PT. Japfa Comfeed Tbk, jagung kuning, bekatul, bungkil kedelai, minyak kelapa. Penambahan tepung bonggol pisang yang nantinya dicampur sesuai dengan program penyusunan pakan unggas Universitas Brawijaya berbasis microsoft excel. Peralatan yang digunakan Brooder, tempat makan, tempat minum, thermomether, highrometer, ember kecil, sekop, alas plastik, timbangan analitik berkapasitas 0,01 $\mathrm{g}$, dan gelas ukur.

\section{Metode Penelitian}

Metode penelitian yang digunakan pada penelitian ini adalah metode percobaan yang menggunaan Rancangan Acak Lengkap (RAL). Perlakuan yang digunakan adalah 5 perlakuan dan 4 kali ulangan dengan setiap ulangan terdiri dari 5 ekor ayam pedaging, Perlakuan yang diberikan adalah :

$$
\begin{gathered}
\mathrm{P}_{0}=\text { pakan kontrol tanpa tepung bonggol } \\
\text { pisang } \\
\mathrm{P}_{1}=97,5 \% \text { pakan kontrol }+ \text { tepung bonggol } \\
\text { pisang } 2,5 \% \\
\mathrm{P}_{2}=95 \% \text { pakan kontrol }+ \text { tepung bonggol } \\
\text { pisang } 5 \% \\
\mathrm{P}_{3}=92,5 \% \text { pakan kontrol }+ \text { tepung bonggol } \\
\text { pisang } 7,5 \% \\
\mathrm{P}_{4}=90 \% \text { pakan kontrol }+ \text { tepung bonggol } \\
\text { pisang } 10 \%
\end{gathered}
$$

Variabel yang diukur adalah berat karkas, persentase karkas, dan lemak abdominal ayam pedaging.

\section{Prosedur Penelitian}

Persiapan dimulai dari persiapan kandang selama 2 minggu, persiapan yang dilakukan adalah sanitasi kandang, dikapur dan disucihamakan, sanitasi alat-alat yang digunakan serta penataan sekam serta pengapuran di dalam litter kandang. Selanjutnya kandang di semprotkan dengan desinfektan. Pemasangan tirai plastik dimaksudkan untuk udara dingin masuk 
pada saat brooding. Kandang dibuat sekat dengan ukuran 100x100x70 cm. Setiap sekat diberi tempat pakan dan tempat minum. Pemberian kode pada setiap sekat kandang dan pemberian lampu penerangan pada setiap kandang, pemasangan gasolek sebagai pemanas ruangan. Chick In pemanas dinyalakan minimal \pm 6 jam sebelum DOC tiba (pre-heating), agar temperatur brooding sudah cukup stabil saat DOC masuk dan liter sudah hangat. Air minum yang disarankan adalah air gula 2-3\% (20$30 \mathrm{~g}$ gula merah per liter air minum).

Masa brooding dilakukan selama 14 hari. Brooder (gasolek) dinyalakan selama $24 \mathrm{jam} /$ hari dengan tirai ditutup, setelah itu tirai dibuka pada pagi hari sampai dengan sore hari, sedangkan pada malam hari di tutup kembali.Pemberian pakan dilakukan pada pagi hari pukul 07.00 WIB dengan perlakuan yang telah ditentukan. air minum diberikan secara ad libitum. Tempat minum pada ayam tidak boleh kotor maka dari itu dilakukan pencucian tempat minum. Pencucian dilakukan pagi hari pukul 08.00 WIB dan siang hari pada pukul 16.00 WIB.

\section{Variabel Pengamatan Berat Karkas}

Berat karkas merupakan berat ayam yang sudah dipotong dikurangi berat darah, bulu, kaki, kepala, leher, dan seluruh isi organ dalam kecuali paru-paru dan ginjal (Subekti, Abbas, Zura, 2012).

$$
\begin{aligned}
\text { Berat karkas }= & \text { Berat hidup }- \text { berat non } \\
& \text { karkas (kepala, bulu, kaki, } \\
& \text { darah, leher, dan organ } \\
& \text { dalam kecuali paru-paru } \\
& \text { dan ginjal) }
\end{aligned}
$$

\section{Persentase Karkas}

Berdasarkan berat karkas dikalikan dengan $100 \%$, karkas yang diukur adalah ayam yang sudah dihilangi darah, bulu, kaki, kepala, leher, dan seluruh isi organ dalam kecuali paru-paru dan ginjal (Jola, Rompis, dan Mangelep, 2017).

$$
\% \text { Karkas }=\frac{\text { Berat Karkas }(\mathrm{g}) \text { x } 100 \%}{\text { Berat hidup }(\mathrm{g})}
$$

\section{Lemak Abdominal}

Berat lemak abdominal dengan cara menimbang berat lemak yang melekat di dalam perut ayam yang meliputi jantung, rempela, dinding perut, ginjal, dan kloaka. Persentase lemak abdominal berkaitan dengan berat karkas yang dipotong (Dou, Shi, Sun, Wang, 2009).

$\%$ Lemak Abdominal $=$

Berat Lemak Abdominal (g) x 100\%

Berat karkas (g)

\section{HASIL DAN PEMBAHASAN}

\section{Pengaruh Perlakuan Terhadap Berat Karkas}

Hasil analisis statsistik menunjukan bahwa penambahan tepung bonggol pisang di dalam pakan memberikan pengaruh yang tidak nyata $(\mathrm{P}>0,05)$ terhadap berat karkas. Nilai rata-rata berat karkas dapat dilihat pada Tabel 1.

Tabel 1. Nilai Rata-Rata Berat Karkas Dengan Penambahan Bonggol Pisang

\begin{tabular}{cl}
\hline Perlakuan & Berat karkas (g/ekor) \\
\hline $\mathrm{P}_{0}$ & $1012,25 \pm 91,50$ \\
$\mathrm{P}_{1}$ & $1015,50 \pm 92,69$ \\
$\mathrm{P}_{2}$ & $1024,75 \pm 63,27$ \\
$\mathrm{P}_{3}$ & $1026,75 \pm 102,39$ \\
$\mathrm{P}_{4}$ & $1115,25 \pm 247,36$ \\
\hline
\end{tabular}

Hasil rata-rata berat karkas (g/ekor) yang tertinggi hingga yang terendah adalah $\mathrm{P}_{4}(1115,25 \pm 247,36), \mathrm{P}_{3}(1026,75 \pm 102,38)$, $\mathrm{P}_{2}(1024,75 \pm 63,27), \mathrm{P}_{1}(1015,5 \pm 92,69), \mathrm{P}_{0}$ (1012,25 $\pm 91,50)$. Hasil penelitian menunjukkan bahwa semakin tinggi penambahan bonggol pisang di dalam pakan menunjukkan bahwa semakin tinggi berat karkas yang dihasilkan. 
Berdasarkan data yang didapatkan pada Tabel 1 pemanfaatan tepung bonggol pisang dapat meningkatkan hasil karkas ayam pedaging dikarenakan di dalam bonggol pisang mengandung karbohidrat $89,76 \%$ yang tinggi dan pati dengan partikel tepung yang rapuh hal ini akan memudahkan dalam proses pencernaan pada ternak unggas. Fungsi utama karbohidrat sebagai sumber energi, karbohidrat yang tersusun dari unsur $\mathrm{H}$ dan $\mathrm{O}$ yang berguna bagi sumber energi untuk unggas adalah gulagula, pati (Aswandi, 2016). Dewi, Sudjarwo, dan Sjofjan (2014) menjelaskan bahwa ayam akan cenderung meningkatkan konsumsi pakan apabila kandungan energi pakan rendah, sehingga diikuti dengan peningkatan berat hidup yang tinggi pula dan apabila kandungan energi pakan ditingkatkan maka konsumsi pakan akan menurun.

Berat hidup yang besar akan sejalan dengan berat karkas yang besar pula serta sebaliknya. Salam, Fatahilah, dan Sunarti (2013) menjelaskan bahwa ayam yang diberi pakan dengan protein rendah dan energi yang tinggi akan menghasilkan lemak lebih tinggi karena energi yang berlebih dan tidak digunakan akan diubah menjadi lemak sekitaran perut (abdominal) serta pembentukan jaringan-jaringan tubuh. Penimbunan lemak ini dapat menyebabkan menurunnya berat karkas yang dapat dikonsumsi, karena tidak termasuk bagian karkas. Hidayat (2015) menyatakan bahwa ayam pedaging yang dipelihara dalam suhu yang panas akan mengurangi aktivitas makannya, dikarenakan untuk menyesuaikan kondisi lingkungan yang berada disekitarnya. Konsumsi pakan yang sedikit inilah yang menyebabkan rendahnya konsumsi energi yang berada di dalam pakan yang menyebabkan menurunya berat hidup yang dihasilkan sehingga dengan menurunya berat hidup ini akan berdampak terhadap hasil produksi berat karkas ayam pedaging.

\section{Pengaruh Perlakuan Terhadap Persentase Karkas}

Hasil analisis statistik menunjukan bahwa penambahan tepung bonggol pisang di dalam pakan memberikan pengaruh yang nyata $(\mathrm{P}<0,05)$ terhadap persentase berat karkas dapat dapat dilihat pada Tabel 2.

Tabel 2. Nilai Rata-Rata Persentase Berat Karkas Dengan Penambahan Bonggol Pisang

\begin{tabular}{cl}
\hline Perlakuan & Persentase Karkas $(\%)$ \\
\hline $\mathrm{P}_{0}$ & $63,14 \pm 1,46^{\mathrm{a}}$ \\
$\mathrm{P}_{1}$ & $64,27 \pm 2,52^{\mathrm{ab}}$ \\
$\mathrm{P}_{2}$ & $61,32 \pm 2,81^{\mathrm{a}}$ \\
$\mathrm{P}_{3}$ & $62,75 \pm 1,99^{\mathrm{a}}$ \\
$\mathrm{P}_{4}$ & $67,72 \pm 3,63^{\mathrm{b}}$ \\
\hline Keterangan : & ${ }^{\text {a,b }}$ Superskip yang berbeda \\
& pada kolom yang sama \\
& menunjukkan perbedaan \\
& pengaruh nyata $(\mathrm{P}<0,05)$
\end{tabular}

Hasil rata-rata perhitungan statistik persentase berat karkas dari yang tertinggi hingga terendah persentase karkas (\%) adalah $\mathrm{P}_{4}(67,72 \pm 3,63), \mathrm{P}_{1}(64,27 \pm 2,5), \mathrm{P}_{0}$ $(63,14 \pm 1,46), \quad \mathrm{P}_{3} \quad(62,75 \pm 1,99), \quad \mathrm{P}_{2}$ $(61,32 \pm 2,81)$. Hasil penelitian menunjukan bahwa semakin tinggi penambahan bonggol pisang di dalam pakan menunjukkan bahwa semakin tinggi persentase berat karkas yang dihasilkan.Rata-rata persentase karkas yang didapatkan adalah 63,14-67,72\% dengan rata-rata yang paling besar didapatkan oleh $\mathrm{P}_{4}$ dengan $67,72 \%$. Hasil tersebut menunjukan bahwa dalam pemberian tepung bonggol pisang di dalam pakan dapat diterima karena memiliki produksi sesuai standar dalam pembentukan karkas ayam pedaging. Rata-rata hasil yang didapatkan hampir sama dengan hasil penelitian yang didapatkan oleh Siregar (2011) bahwa persentase yang dihasilkan kisaran 60,52$69,91 \%$ Hal ini di dukung oleh Nisak (2016) menyatakan bahwa persentase karkas dipengaruhi oleh laju pertumbuhan dan komposisi tubuh yang meliputi distribusi berat dan komponen karkas. 
Karkas merupakan bagian tubuh yang
sangat menentukan produksi ayam pedaging. Produksi ini berhubungan erat dengan besarnya persentase karkas yang didapat cukup bervariasi dengan kisaran 65$75 \%$ yang dianggap baik dalam produksi karkas pada ayam pedaging. Persentase karkas berbanding lurus dengan berat hidup, jadi semakin meningkat berat hidup maka persentase berat karkas yang didapatkan semakin meningkat pula hal ini didukung oleh Risnajani (2012) bahwa lemak dan organ dalam merupakan hasil ikutan yang tidak dihitung dalam persentase karkas sehingga jika lemak tinggi maka persentase karkas akan rendah, dijelaskan oleh Daud (2006) bahwa persentase karkas berhubungan erat dengan jenis kelamin, umur serta berat badan. Semakin meningkat umur maka berat badan akan mengalami peningkatan pula. Meningkatnya berat badan ini diikuti dengan menurunnya kandungan lemak abdominal sehingga produksi daging yang dihasilkan semakin meningkat.

Persentase karkas berkaitan dengan berat hidup ayam, apabila berat karkas yang dihasilkan tidak mengalami kenaikan akan tetapi persentase karkas yang dihasilkan meningkat dapat dikatakan bahwa berpengaruh terhadap berat organ dalam. Kenaikan persentase karkas ini menunjukan bahwa nilai berat organ dalam rendah dikarenakan penyerapan nutrisi yang baik dari ayam pedaging. Usus halus termasuk kedalam organ dalam berfungsi sebagai penggerak aliran pakan serta meningkatkan penyerapan zat makanan. Usus halus dilengkapi dengan jonjot usus yang lembut dan menonjol sehingga penyerapan zat makanan dapat dilakukan secara maksimal. Perkembangan usus halus ini dipengaruhi oleh kandungan serat kasar di dalam pakan (Wijaya, 2010).

Seiring dengan peningkatan penambahan tepung bonggol pisang terjadinya penurunan pemberian protein di dalam pakan akan tetapi persentase karkas yang didapatkan semakin tinggi. Sibarani, Yunianto, dan Mahfudz (2014) melaporkan bahwa efisiensi pakan yang baik bisa terjadi karena perlakuan dapat menyebabkan terjadinya peningkatan permukaan serap pada sel epitel jejunum, permukaan daya serap yang luas dapat meningkatkan kecernaan asam amino, pati, lemak, dan vitamin yang ada pada pakan walaupun terjadi penurunan level protein pakan.

\section{Pengaruh Perlakuan Terhadap Lemak Abdominal}

Hasil analisis statsistik menunjukkan bahwa penambahan tepung bonggol pisang di dalam pakan memberikan pengaruh yang tidak nyata $(\mathrm{P}>0,05)$ terhadap berat karkas. Data perhitungan statistik berat karkas dapat dilihat pada Tabel 3.

Tabel 3. Nilai Rata-Rata Lemak Abdominal Dengan Penambahan Bonggol Pisang

\begin{tabular}{cc}
\hline Perlakuan & Lemak Abdominal $(\%)$ \\
\hline $\mathrm{P}_{0}$ & $2,30 \pm 0,23^{\mathrm{B}}$ \\
$\mathrm{P}_{1}$ & $2,24 \pm 0,30^{\mathrm{B}}$ \\
$\mathrm{P}_{2}$ & $1,97 \pm 0,31^{\mathrm{B}}$ \\
$\mathrm{P}_{3}$ & $1,93 \pm 0,22^{\mathrm{B}}$ \\
$\mathrm{P}_{4}$ & $1,21 \pm 0,09^{\mathrm{A}}$ \\
\hline
\end{tabular}

\begin{aligned} \hline Keterangan : & A,B Superskip yang berbeda \\ & pada kolom yang sama \\ & menunjukkan perbedaan \\ & pengaruh sangat nyata \\ & $(\mathrm{P}<0,01)\end{aligned}$

Hasil rata-rata berat karkas (g/ekor) yang tertinggi hingga yang terendah adalah $\mathrm{P}_{4}(1115,25 \pm 247,36), \mathrm{P}_{3}(1026,75 \pm 102,38)$, $\mathrm{P}_{2}(1024,75 \pm 63,27), \mathrm{P}_{1}(1015,5 \pm 92,69), \mathrm{P}_{0}$ (1012,25 $\pm 91,50)$. Hasil penelitian menunjukkan bahwa semakin tinggi penambahan bonggol pisang di dalam pakan menunjukkan bahwa semakin rendah lemak abdominal yang dihasilkan. Tabel 3 . menunjukan bahwa semakin tinggi level pemberian tepung bonggol pisang dalam pakan maka lemak abdominal yang dihasilkan semakin menurun. Hal ini diduga semakin tinggi level serat kasar maka semakin rendah kandungan lemak abdominal karena energi digunakan untuk merombak serat kasar dalam pakan sehingga tidak adanya energi yang tersisa untuk 
pembentukan lemak abdominal. Hal ini didukung oleh Sandi, Palupi, dan Amyesti (2012) bahwa lemak tubuh dipengaruhi oleh serat kasar dalam pakan, karena tingginya serat kasar di dalam pakan mampu mengikat asam empedu. Asam empedu ini berguna sebagai pengemulsi makanan berlemak sehingga mudah menghidrolisis oleh enzim lipase. Aktivitas enzim empedu berkurang dikarenakan sebagian besar asam empedu diikat oleh serat kasar maka emulsi partikel lipida yang terbentuk lebih sedikit. Penurunan aktivitas enzim ini menyebabkan pengurangan lipida yang terserat serta banyak dikeluarkan dalam bentuk kotoran karena tidak diserap oleh tubuh, sehingga jaringan tubuh akan sedikit mengandung lipid.

Kandungan energi pakan turun dengan seiring peningkatan pemberian bonggol di dalam pakan pada setiap perlakuan sehingga energi yang berlebihan dapat memicu dalam terbentuknya lemak abdominal. Lemak abdominal terbentuk karena energi yang merupakan hasil dari proses metabolisme zat makanan yang masuk ke dalam tubuh ayam melebihi tingkat kebutuhan yang diperlukan oleh tubuh, baik kebutuhan untuk hidup pokok maupun untuk kebutuhan berproduksi. Subekti, dkk. (2012) menyatakan bahwa pembentukan lemak abdominal di dalam tubuh ayam terjadi karena adanya kelebihan energi yang didapatkan oleh pakan yang dikonsumsinya. Energi pada ayam berasal dari karbohidrat serta cadangan lemak. Karbohidrat di dalam tubuh yang tidak digunakan akan disimpan dalam bentuk lemak tubuh yang berada disekeliling jeroan dan dibawah kulit. Massolo, Mujnisa, dan Agustina (2010) menyatakan bahwa ayam yang mengkonsumsi pakan yang mengandung serat kasar yang lebih tinggi mempunyai kandungan lemak abdomen yang lebih rendah dibandingkan dengan pakan yang memiliki serat kasar yang lebih rendah.

Lemak abdominal pada penelitian ini mendapatkan hasil berkisar antara 1,21\%$2,30 \%$ pemeliharaan selama 5 minggu, hasil ini lebih rendah daripada hasil penelitian
Syukron (2006) yang juga dipelihara selama 5 minggu dengan kisaran antara 1,44-2,26\% berat hidup bahwa semakin rendah kualitas lemak abdominal menunjukan bahwa kondisi perlemakan cenderung baik dengan seiring meningkatnya kualitas karkas yang didapatkan, sebagaimana yang telah diketahui bahwa lemak abdominal adalah hasil ikutan yang mempengaruhi kualitas karkas. Yuniastuti (2002) melaporkan bahwa tinggi rendahnya kualitas karkas ayam pedaging ditentukan dari jumlah lemak abdominal yang terdapat dari ayam pedaging, timbunan lemak ini dapat mengindikasikan bahwa terjadi pemborosan pakan karena lemak abdominal merupakan bagian yang tidak dapat dimanfaatkan (Hidayat, 2015).

\section{KESIMPULAN}

Berdasarkan hasil penelitian dapat disimpulkan bahwa pemanfaatan tepung bonggol pisang dalam pakan ayam pedaging mampu mempertahankan berat karkas serta meningkatkan persentase karkas dan menurunkan lemak abdominal ayam pedaging dengan pemberian pada level $10 \%$.

\section{DAFTAR PUSTAKA}

Aswandi. (2016). Performa ayam ras pedaging yang mendapat ransum komersil mengandung tepung bonggol pisang. JITP, 4(3), 98-105.

Daud, M. (2006). Persentase dan kualitas karkas ayam pedaging yang diberi probiotik dan prebiotik dalam ransum (the carcass percentage and carcass quality of broilers given probiotics and prebiotics in the ration). Jurnal Ilmu Ternak, 6(2), 126-131. https://doi.org/10.24198/JIT.V6I2.2280

Direktorat Jenderal Peternakan dan Kesehatan Hewan. (2016). Produksi daging ayam ras pedaging menurut provinsi. 
F, D. F., Sudjarwo, E., \& Sjofjan, O. (2014). Pengaruh penggunaan beberapa varietas tepung jagung dalam pakan terhadap kualitas karkas ayam pedaging. Repositori $U B, 1-12$.

Hidayat, C. (2015). Penurunan deposit lemak abdominal pada ayam pedaging melalui manajemen pakan. Wartazoa, 25(3), 125-134.

Jola J. M. R. L, Rompis, E. G., \& Mangelep, C. (2016). Kualitas karkas ayam pedaging yang diberi ransum mengandung limbah sawi. ZOOTEC, $37(1), 1-7$.

Massolo, R., Mujnisa, A., \& Agustina, L. (2017). Persentase karkas dan lemak abdominal broiler yang diberi prebiotik inulin umbi bunga dahlia (Dahlia variabillis). Buletin Nutrisi Dan Makanan Ternak, 12(2), 50-58.

Michalczuk, M., Łukasiewicz, M., Zdanowska-Sąsiadek, Ż., \& Niemiec, J. (2014). Comparison of selected quality attributes of chicken meat as affected by rearing systems. Polish Journal of Food and Nutrition Sciences, 64(2), 121-126. https://doi.org/10.2478/v10222-012-0096-y

Nisak, K. (2016). Kombinasi tepung kulit pisang dan kulit ubi dalam ransum terhadap lemak abdomen dan persentase karkas ayam broiler. Jurnal Ilmiah Peternakan, 2(4), 27-30.

Risnajati, D. (2017). Perbandingan bobot akhir, bobot karkas dan persentase karkas berbagai strain broiler. Sains Peternakan, 10(1), 11-14. https://doi.org/10.20961/sainspet.v10i1.4808

Rosidin, R., Yuliati, K., \& Siti Hanggita, R. (2018). Pengaruh suhu dan lama pengeringan terhadap mutu silase limbah pengolahan kodok beku (rana sp.) yang dikeringkan dengan penambahan dedak padi. Jurnal FishtecH, 1(1), 78-90.

Salam, S., Fatahilah, A., Sunarti, D., \& Isroli, I. (2017). Berat karkas dan lemak abdominal ayam broiler yang diberi tepung jintan hitam (nigella sativa) dalam ransum selama musim panas. Sains Peternakan, 11(2), 84-90. https://doi.org/10.20961/sainspet.v11i2.4844

Sandi. S, R., Palupi, \& Amyesti. (2012). Pengaruh penambahan ampas tahu dan dedak fermentasi terhadap karkas, usus dan lemak abdomen ayam broiler. Agrinak, 2(1), 1-5.

Sibarani. J, Yunianto, V. D., \& Mahfudz, L. D. (2016). Persentase karkas dan non karkas serta lemak abdominal ayam broiler yang diberi acidifier asam sitrat dalam pakan double step down. Animal Agriculture Journal, 3(2), 273-280.

Siregar, Z. (n.d.). Persentase karkas dan pertumbuhan organ dalam ayam broiler pada frekuensi dan waktu pemberian pakan yang berbeda. Fakultas Peternakan, Institut Pertanian Bogor: Skripsi. Departemen Ilmu Produksi Dan Teknologi Peternakan.

Subekti, K., Abbas, H., \& Zura, K. A. (2012). Kualitas karkas (berat karkas, persentase karkas dan lemak abdomen) ayam broiler yang diberi kombinasi cpo (crude palm oil) dan vitamin c (ascorbic acid) dalam ransum sebagai anti stress. Jurnal Peternakan Indonesia, 14(3), 447-453.

Sutardi, T. (2001). Revitalisasi peternakan sapi perah melalui penggunan ransum berbasis limbah perkebunan dan suplementasi mineral organik (RU VII 1). Kantor Menteri Negara Riset dan teknologi. Lembaga Ilmu Pengetahuan Indonesia: Laporan Akhir. 
Syukron, M. (2006). Kandungan lemak dan kolesterol daging serta persentase organ dalam ayam broiler yang diberi ransum finisher dengan penambahan kepala udang. Institut Pertanian Bogor: Skripsi. Fakultas Peternakan.

Wijaya, G. H. (2010). Persentase karkas, lemak abdominal dan organ dalam ayam broiler yang diberi ransum dengan penambahan cassabio. Institut Pertanian Bogor: Skripsi. Departemen Ilmu Produksi Dan Teknologi Peternakan, Fakultas Peternakan.

Yuniastuti, A. (2002). Efek pakan berserat pada ransum ayam terhadap kadar lemak dan kolesterol daging broiler. JITV, 9(3), 175-183. 